\title{
ANALISIS PUTUSAN HAKIM PENGADILAN TINDAK PIDANA KORUPSI DENPASAR (Putusan No: 42/Pid.Sus-TPK/2015/PN Dps)
}

\author{
I Made Suartana, I Made Minggu Widyantara, I Nyoman Gede Sugiartha \\ Fakultas Hukum Universitas Warmadewa, Denpasar-Bali, Indonesia
}

\begin{abstract}
Abstrak
Maksud dan tujuan penelitian ini adalah menganalisa penyimpangan kewenangan pada perintah perjalanan dinas yang berimplikasi pada terjadinya korupsi. Isu hukum yang muncul dari penelitian ini meliputi dasar hukum yang dipergunakan Majelis Hakim Pengadilan Tindak Pidana Korupsi of Denpasar dalam mempertimbangkan dan menjatuhkan sanksi pidana pada Putusan No. 42/Pid.Sus-TPK/2015/Pengadilan Negeri Denpasar dan analisa yuridis Majelis Hakim Pengadilan Tindak Pidana Korupsi Denpasar dalam mengambil keputusan atas perkara No. 42/Pid.Sus-TPK/2015/ of Pengadilan Negeri Denpasar. Penelitian ini merupakan penelitian hukum normatif yang mempergunakan beberapa pendekata, seperti pendekatan perundang-undangan (statute approach), pendekatan konseptual (conceptual approach), dan pendekatan kasus (case approach). Hasil penelitian menunjukkan bahwa tindak pidana korupsi merupakan kejahatan yang secara khusus diatur dengan Undang-Undang No. 20 Tahun 2001, yang keberadaannya merupakan revisi atas Undang-Undang UndangUndang No. 31 Tahun 1999 yang juga mengatur mengenai pemberantasan kejahat tindak pidana korupsi. Sesuai Putusan No. 42/Pid.Sus-TPK/2015/ of Pengadilan Negeri Denpasar, seorang terdakwa telah terbukti melanggar ketentuan Pasal 3 Undang-Undang No. 31 Tahun 1999 yang kemudian diamandemenkan menjadi UndangUndang No. 20 Tahun 2001 mengenai Pemberantasan Tindak Pidana Korupsi. Hal itu karena berdasarkan dengan putusan tersebut, semua tindakan yang dilakukan oleh terdakwa dan telah terbukti melakukan unsurunsur tindak pidana yang didakwakan kepadanya pada dakwaan subsidair.
\end{abstract}

Kata Kunci: Korupsi; Penyalahgunaan Wewenang; Perjalanan Dinas

\begin{abstract}
The purpose and objective of this study is to analyze deviations in authority on official travel orders which have implications for corruption. The legal issues arising to be studied in this research are the legal basis used by the Panel of Judges at the Corruption Court of Denpasar in deciding and imposing criminal sanctions on Decision No. 42/Pid.Sus-TPK/2015/ of Denpasar District Court and the juridical analysis on the Denpasar Corruption Court Judges in making decisions on case No. 42/Pid.Sus-TPK/2015/ of Denpasar District Court. This research is a normative legal research which uses several approaches, such as statute approach, conceptual approach, and case approach. The results of the study indicate that the criminal act of corruption is a crime specifically regulated by Law No. 20 of 2001, whose existence is a revision of Law no. 31 of 1999 which also regulates the eradication of criminal acts of corruption. In accordance with Decision No. 42/Pid.Sus-TPK/2015/ of Denpasar District Court, a defendant has been proven to have violated the provisions of Article 3 of Law No. 31 of 1999 which was later amended into Law No. 20 of 2001 regarding the Eradication of Corruption Crime. This is because based on this verdict, all the acts have been committed by the defendant and he is proven to have committed the elements of the criminal act that was charged to him on the subsidiary charges.
\end{abstract}

Keywords: Corruption; Abuse of Authority; Business Trip

\section{PENDAHULUAN}

Korupsi merupakan suatu kejahatan yang oleh pemerintah Indonesia telah dikategorikan sebagai suatu kejahatan yang luar biasa (extraordinary crime) (Ifrani, 2017; Hatta, 2019), karena dampaknya sangat dirasakan oleh rakyat dan sangat menghambat tercapainya sistem pemerintahan yang bersih dan baik yang muaranya diharapkan dapat menimbulkan kesejahtraan bagi bangsa dan Negara (Waluyo, 2014). Oleh karena itu pemerintah juga perlu melakukan pencegahan dan penindakan kejahatan korupsi 
dengan cara-cara yang serba luar biasa pula. Upaya untuk mencegah munculnya korupsi dalam sistem pemerintahan Negara Republik Indonesia sesungguhnya sudah cukup lama digaungkan oleh pemerintah Indonesia, namun demikian pada kenyataannya kejahatan korupsi kian hari tampak semakin merajarelala dan dilakukan dengan modus yang beraneka ragam, sehingga terkesan kejahatan korupsi tidak akan mudah untuk diberantas dengan metode-metode yang bersifat klasik dan dalam waktu yang relatif singkat.

Korupsi merupakan kejahatan yang bersifat sistematis dan dilakukan secara berjamaah (Waluyo, 2014), yang saat ini kerap kita temukan tidak hanya dalam system pemerintahan yang berlangsung pada pemerintah pusat namun juga terjadi pada system pemerintahan daerah baik provinsi maupun kabupaten. Secara spesifik penulis ingin membahas mengenai kasus korupsi yang terjadi pada pemerintah daerah Kabupaten Gianyar, Bali yaitu mengenai kejahatan/pidana korupsi yang terjadi dalam Perjalanan Dinas pemerintah kabupaten gianyar, yang dilakukan oleh oleh 14 orang Pegawai Negeri Sipil (PNS) Pemertintah Kabupaten Gianyar pada tahun 2012. Yang perkaranya kemudian ditangani oleh Pengadilan Tindak Pidana Korupsi Denpasar, Bali.

Untuk membahas lebih lanjut kasus tersebut di atas, penulis telah menetapkan rumusan masalah yang akan menjadi objek kajian ini, yakni sebagai berikut:

1. Bagaimana dasar hukum pertimbangan majelis hakim pengadilan tindak pidana korupsi Denpasar dalam menjatuhkan sanksi pidana pada Putusan No. 42/Pid.Sus-TPK/2015/ Pengadilan Negeri Denpasar?

2. Bagaimana analisis yuridis majelis hakim dalam memutus Putusan Nomor: 42/Pid.SusTPK/2015/ Pengadilan Negeri Denpasar?

Adapun tujuan dari penelitian ini adalah:

1. Untuk mengetahui Dasar Hukum yang dipergunakan Majelis Hakim Pengadilan Tindak Pidana Korupsi Denpasar dalam menjatuhkan pidana pada Putusan No. 42/Pid.SusTPK/2015/ Pengadilan Negeri Denpasar.

2. Untuk mengetahui Analisis Yuridis Majelis Hakim dalam mempertimbangkan Tindak Pidana Korupsi dalam Putusan Nomor: 42/Pid.Sus-TPK/2015/PN Dps.

\section{METODE PENELITIAN}

Metode penelitian yang dipergunakan dalam penelitian ini adalah bersifat normatif (Efendi \& Ibrahim, 2018), karena penelitian ini diterapkan dengan melakukan pengkajian melalui pendekatan konseptual dan pendekatan peraturan perundang-undangan. Pendekatan masalah direalisasikan dengan melakukan kajian terhadap peraturan peruandang-undangan yang berlaku dan memiliki relevansi dengan permasalahan yang dibahas dalam penelitian ini sekaligus melakukan pendekatan konseptual dengan cara menganalisis permasalahan melalui konsep hukum yang diambil dari bukubuku serta literatur-literatur yang memiliki relevansi dengan permasalahan yang diteliti (Susanti, 2014).

Sumber Bahan Hukum Dalam Penelitian Ini Yaitu:

a. Bahan-bahan hukum primer yang dipergunakan penulis adalah bahan hukum yang memiliki ketentuan hukum yang bersifat mengikat. Yang dalam penelitian ini bahan-bahan hukum primernya adalah: Putusan Pengadilan Tindak Pidana Korupsi Denpasar Nomor: 42/Pid.SusTPK/2015/ Pengadilan Negeri Denpasar; Kitab Undang-undang Hukum Pidana; Kitab Undang-Undang Hukum Acara Pidana; UU No. 31 Th 1999 juncto UU No. 20 Tahun 2001 mengenai Pemberantasan Tindak Pidana Korupsi; serta yurisprudensi Pengadilan.

b. Bahan hukum sekunder merupakan bahan hukum yang memberikan penjelasan-penjelasan akan teori serta doktrin hukum, yang di antaranya adalah berupa buku-buku bidang hukum, hasil penelitian bidang hukum serta kajian pustaka yang memiliki keterkaitan dengan penelitian ini.

c. Bahan hukum tersier merupakan bahan-bahan yang dapat memberikan penjelasan ataupun petunjuk akan bahan hukum primer maupun sekunder yang ada, sehingga bahan-bahan hukum primer dan sekunder dapat dipergunakan secara tepat guna, misalnya kamus, ensiklopedia, indeks kumulatif dan sebagainya.

Untuk memperoleh bahan hukum yang memiliki relevansi serta korelasi dengan topik penelitian ini, Penulis kemudian melakukan studi kepustakaan untuk kepentingan pengumpulan data. Studi 
kepustakaan yang penulis maksud adalah melakukan pengumpulan data dengan mempelajari bukubuku, dokumen-dokumen, ataupun literatur-literatur yang memiliki relevansi dengan topik penelitian. Dalam penelitian ini, data dianalisis secara deskriptif, dengan maksud untuk memetakan ada atau tidaknya pengaruh suatu gejala dengan gejala lain yang timbul di masyarakat.

\section{HASIL DAN PEMBAHASAN}

Dasar Hukum Pertimbangan Majelis Hakim Pengadilan Tindak Pidana Korupsi Denpasar dalam Putusan Nomor: 42/Pid.Sus-TPK/2015/PN Dps.

Kejahatan korupsi diatur dalam Undang-Undang Nomor 20 Tahun 2001 yang merupakan perubahan dari Undang-Undang Nomor 31 Tahun 1999 mengenai Pemberantasan Kejahatan Korupsi.

Terdakwa dalam perkara Tindak Pidana Korupsi yaitu: Terdakwa 1. Dewa Made Putra,SH,M.Si, dengan terdakwa 2. Ketut Ritama, S.Sos, terdakwa 3. S.A.M. Ika Kencana Dewi,SH, terdakwa 4. Ni Kt. Juniantari, A.Md, terdakwa 5. I Kt. Puja, terdakwa 6. I Md. Darmaja, terdakwa 7. I Km. Yastra, terdakwa 8. I Md. Wirawan, terdakwa 9. I Ny. Sulandra, terdakwa 10. Ni Wy. Suciasih, terdakwa 11. Ni Kt. Suniawati,SH, terdakwa 12. Ni Md. Ayu Purniasih,S.Sos, terdakwa 13. A.A. Istri Agung Yunariwati,SE dan terdakwa 14. I Md. Suparta. Semua terdakwa adalah PNS pada Dinas Pendapatan Daerah Pemerintah Kabupaten Gianyar.

Berdasarkan fakta-fakta yang terungkap dipersidangan berupa keterangan saksi-saksi yang diberikan dibawah sumpah, pendapat ahli, alat bukti surat, keterangan para terdakwa dan barang bukti yang diajukan dipersidangan, maka diperoleh fakta-fakta hukum berdasarkan pemeriksaan di Pengadilan yaitu sebagai berikut:

1. Bahwa para terdakwa $1 \mathrm{~s} / \mathrm{d} 14$ yang mendapat tugas sesuai dengan Surat Tugas No.:800/0547/Dipenda tanggal 25 Oktober 2012 ditugaskan oleh Kepala Dinas Pendapatan Kabupaten Gianyar untuk melakukan perjalanan dinas ke Dinas Pendapatan Pengelolaan Keuangan dan Aset (DPPK) Kota Depok pada tanggal 29 s/d 31 Oktober 2012 dalam rangka study banding crass program/ system tunggu pada Dinas Pendapatan Pengelolaan Keuangan dan Aset Kota Depok dan seluruh biaya kegiatan tersebut di bebankan kepada APBD Pemerintah Kabupaten Gianyar sebasar Rp. 94.900.000,- (Sembilan Puluh Empat Juta Sembilan Ratus Ribu Rupiah).

2. Kemudian pada tanggal 29 Oktober 2012 sekirta pukul 04.00 Wita terdakwa 1 s/d 4, dengan menggunakan mobil travel Timbul Buana Abadi berangkat dari Gianyar menuju Bandara Ngurah Rai Denpasar meneruskan perjalanan menuju Jakarta dengan menggunakan pesawat Garuda GA 423 selanjutnya melanjutkan perjalanan menuju Bangkok Thailand sampai dengan hari Rabu tanggal 31 Oktober 2012.

3. Sedangkan para terdakwa $5 \mathrm{~s} / \mathrm{d} 14$ pada tanggal yang sama yaitu Senin tanggal 29 Oktober 2012 sekitar jam 08.00 Wita dari Gianyar mengunakan mobil Travel Timbul Buana Abadi milik saksi I Made Sudianga berangkat menuju Bandara Ngurah Rai Denpasar untuk selanjutnya meneruskan perjalanan ke Jakarta dengan pesawat Garuda 427 pukul 11.20 Wita.

4. Bahwa terdakwa $5 \mathrm{~s} / \mathrm{d} 14$ dengan diantar oleh mobil travel pergi melakukan persembahyangan di Pura Gunung Salak, setelah itu para terdakwa kembali ke hotel untuk istirahat, kemudian pada tanggal 30 Oktober 2012 para terdakwa dengan di jemput oleh mobil travel berangkat menuju Dinas Pendapatan Pengelolaan Keuangan dan Asset Pemerintah Kota Depok dengan maksud untuk meminta tandatangan dan cap stempel DPPK Kota Depok guna kelengkapan Surat Perjalanan Dinas yang dikeluarkan oleh Pemda Gianyar Bali, saat di kantor DPPK Kota Depok hanya terdakwa I Ketut Puja dan terdakwa I Made Darmaja yang masuk ke salah satu ruangan DPPK Kota Depok sedangkan yang lain menungu di luar, selanjutnya oleh saksi Achmad Karyaman, S.Ip. SPPD tersebut ditandatangani dan di stempel dan kemudian diserahkan kembali melalui stafnya selanjutnya para terdakwa kembali ke Jakarta dengan mobil travel dan jalan-jalan berbelanja di Mangga Dua Jakarta.

5. Bahwa kemudian pada tanggal 31 Oktober 2012 terdakwa 5 s/d 14, bersiap-siap kembali ke Denpasar dan pada saat menunggu di Bandara Sukarno Hatta Jakarta mereka para terdakwa bertemu dengan terdakwa 1 s/d 4 yang baru kembali dari Bangkok Thailand dan selanjutnya bersama-sama kembali ke Denpasar pukul 18.45 Wib menggunakan pesawat Garuda GA 426. 
6. Bahwa para terdakwa setelah menerima uang perjalanan dinas tersebut yang seharusnya dipergunakan untuk kepentingan study banding telah menyalahgunakan kewenangan yang diberikan guna kepentingan pribadinya dan bertentangan dengan Peraturan Bupati Gianyar No.7 tahun 2011 tanggal 1 Pebruari 2011 tentang Perjalanan Dinas.

7. Akibat perbutan para terdakwa $1 \mathrm{~s} / \mathrm{d} 14$ tersebut mengakibatkan kerugian Negara kurang lebih sebesar Rp. 94.900.000,- (Sembilan Puluh Empat Juta Sembilan Ratus Ribu Rupiah), sebagaimana Laporan Hasil Audit BPKP Perwakilan Prov. Bali Nomor: SR-857/PW22/5/2013 tanggal 16 Desember 2013.

Para terdakwa dimajukan kedalam Persidangan dengan dakwaan telah melakukan tindak pidana yang diuraikan dalam Surat dakwaan Jaksa Penuntut Umum yang isinya dapat dikutip sebagai berikut: 1) Primair

Terdakwa dianggap melanggar ketentuan Pasal 2 ayat 1 Undang-Undang No. 31 Tahun 1999 mengenai Pemberantasan Korupsi yang telah diperbaiki dengan Undang-Undang No. 20 Tahun 2001 mengenai Pemberantasan Korupsi.

2) Subsidair

Perbuatan terdakwa telah melanggar Pasal 3 ayat 1 Undang-undang No. 31 Tahun 1999 mengenai Pemberantasan Tindak Pidana Korupsi yang diperbaiki dengan Undang-Undang No. 20 Tahun 2001 mengenai Pemberantasan Tindak Pidana Korupsi.

\section{Analisis Yuridis terhadap Pertimbangan Majelis Hakim Pengadilan Tindak Pidana Korupsi Denpasar dalam Putusan Nomor: 42/Pid.Sus-TPK/2015/PN.Dps}

Dalam kasus tindak pidana korupsi perjalanan dinas yang dilakukan oleh 14 orang PNS Pemda Gianyar, Majelis Hakim Pengadilan Negeri Denpasar "MENGADILI":

1. Menyatakan para terdakwa $1 \mathrm{~s} / \mathrm{d}$ 14, tidak terbukti secara sah dan meyakinkan bersalah melakukan tindak pidana korupsi "secara bersama-sama" sebagaimana dalam dakwaan primair;

2. Membebaskan para terdakwa 1 s/d 14, oleh karena itu dari dakwaan Primair tersebut;

3. Menyatakan para terdakwa $1 \mathrm{~s} / \mathrm{d} 14$, terbukti secara sah dan meyakinkan bersalah melakukan tindak pidana korupsi "secara bersama-sama" sebagaimana dalam dakwaan Subsidair;

4. Menjatuhkan pidana penjara terhadap para terdakwa $1 \mathrm{~s} / \mathrm{d} 14$, selama 1 (satu) tahun;

5. Menghukum kepada para terdakwa 1 s/d 14 dengan pidana denda masing-masing Rp.50.000.000,- (lima puluh juta rupiah) dan apabila denda tidak dibayar, maka dihukum kurungan selama untuk terdakwa 1 (satu) Dewa Made Putra,SH,M.Si selama 3 (tiga) bulan, sedangkan untuk terdakwa $2 \mathrm{~s} / \mathrm{d} 14$ masing-masing selama 2 (dua) bulan;

6. Menyatakan bahwa hukuman yang dijatuhkan kepada para terdakwa dikurangkan seluruhnya dengan masa tahanan yang telah dijalankan;

7. Memerintahkan agar para terdakwa tetap berada dalam tahanan;

8. Menghukum kepada para terdakwa $1 \mathrm{~s} / \mathrm{d} 14$ untuk membayar uang perkara masing-masing sebesar Rp. 5.000,- (Lima Ribu Rupiah).

\section{SIMPULAN DAN SARAN}

\section{Simpulan}

Dari pembahasan tersebut di atas dapat disimpulkan beberapa hal:

1. Para terdakwa divonis tidak bersalah melanggar Pasal 2 ayat (1) UU No. 31 Tahun 1999 Jo. UU No. 20 Tahun 2001 mengenai Pemberantasan Korupsi oleh karena tidak terpenuhinya satu unsur di dalam Pasal tersebut yaitu unsur "secara melawan hukum" dan Terdakwa terbukti melanggar Pasal 3 UU No. 31 Tahun 1999 yang telah dirubah dengan UU No. 20 Tahun 2001 Tentang Pemberantasan Tindak Pidana Korupsi karena semua unsur-unsur dalam dakwaan subsidair telah terpenuhi.

2. Pengadilan Negeri Denpasar memutus para terdakwa secara sah dan meyakinkan tidak terbukti bersalah melakukan tindak pidana sebagaimana dakwaan primair dan kepadanya secara hukum wajib dibebaskan dari dakwaan Primair tersebut dan disisi lain Majelis Hakim Pengadilan Negeri Denpasar menyatakan bahwa para terdakwa secara sah dan meyakinkan terbukti bersalah melakukan tindak pidana sebagaimana pada dakwaan Subsidair. 


\section{Saran}

Dari simpulan tersebut di atas, penulis dapat memberikan saran yaitu:

1 Menentukan dasar hukum putusan perkara ini, hendaknya Majelis Hakim Pengadilan Negeri Denpasar lebih teliti dan cermat dalam menggunakan dasar hukum putusannya agar tidak menyebabkan putusan menjadi batal demi hukum.

2 Majelis Hakim juga hendaknya lebih mengedepankan pendekatan Hukum Administrasi Negara dalam memutus perkara a quo, daripada hanya sekedar menekankan pendekatan hukum tindak pidana korupsi yang tujuan akhirnya adalah pemidanaan (represif), yang pada akhirnya pendekatan yang dipergunakan menjadi terkesan terlalu klasik dan sempit dan mengakibatkan penengakan hukum hanya mampu menimbulkan efek jera (retributif), namun relative gagal memulihkan/ mengembalikan kerugian negara yang dapat dipulihkan melalui penerapan pidana denda yang semestinya lebih di utamakan.

3 Konsekuensi lain dari pendekatan pemidaan yang diterapkan majelis hakim dalam perkara a quo adalah Majelis Hakim terkesan meletakan instrumen hukum pidana pada posisi terdepan (premium remidium) dan terkesan sebagai senjata satu-satunya dalam memutus perkara aquo. Padahal semestinya pemidanaan merupakan upaya terakhir yang harusnya dipergunakan dalam menyelesaikan perkara aquo, karena masih ada upaya hukum lain yang harus dikedapankan oleh majelis hakim dalam memutus perkara aquo yaitu hukum administrasi, karena instrumen hukum yang utama untuk mewujudkan pemerintahan yang bersih dan baik adalah melalui hukum administrasi dan dalam menjalankan setiap aktivitasnya, seorang pejabat pegawai negeri sipil juga tunduk dan diatur oleh norma hukum administrasi.

\section{DAFTAR PUSTAKA}

Efendi, J., \& Ibrahim, J. (2018). Metode Penelitian Hukum Normatif dan Empiris. Prenada Media. Hatta, M. (2019). Kejahatan Luar Biasa (Extraordinary Crime). Unimal Press.

Ifrani. (2017). Tindak Pidana Korupsi sebagai Kejahatan Luar Biasa. Al'Adl, 9(3), 319-336.

Susanti, D. O. (2014). Penelitian Hukum (Legal Research). Sinar Grafika.

Waluyo, B. (2014). Optimalisasi Pemberantasan Korupsi di Indonesia. Jurnal Yuridis, 1(2), 169-182.

Undang-Undang Nomor 20 Tahun 2001 Tentang Perubahan Atas UndangUndang Nomor 31 Tahun 1999 Tentang Pemberantasan Tindak Pidana Korupsi

Putusan Hakim Pengadilan Tindak Pidana Korupsi Denpasar Nomor: 42/Pid.Sus-TPK/ 2015/ PN Dps 